\title{
Ethnobotany and micropropagation of Asclepias curassavica L. (Apocynaceae) - a medicinally potent naturalized plant in India
}

\author{
Pratibha Sharma $^{1}$, Jintu Sarma ${ }^{3}$ and C. M. Sarma ${ }^{2}$ \\ ${ }^{1}$ Royal Global University, Guwahati - 781035, Assam, India \\ ${ }^{2}$ Department of Botany, Gauhati University, 781014, Assam, India \\ ${ }^{3}$ Corresponding author: Department of Environmental Science, Tezpur University, 784028, Assam, India \\ E-mail:jsarma88@gmail.com
}

[Received 25.11.2019; Revised 09.12.2019; Accepted 11.12.2019; Published 31.12.2019]

\begin{abstract}
Asclepias curassavica L. (Apocynaceae: Asclepiadoideae) is a high value ethnomedicinal plant species. Considering its ethnomedicinal potentiality current investigation to induce regeneration to producetrue-to-type plantlets. Mainly nodal segments were used for the study. The explants were inoculated on MS-medium augmented with $\mathrm{IBA}+\mathrm{Kn}+\mathrm{CH}, \mathrm{IBA}+\mathrm{Kn}+\mathrm{CH}, \mathrm{BA}+\mathrm{NAA}$, $\mathrm{BA}+\mathrm{NAA}$ and $\mathrm{BA}+\mathrm{IAA}$ shows shoot elongation with many leaves. Combination of NAA $+\mathrm{Kn}$ appeared best for multiple shoot formation with elongation of roots. Combination of $\mathrm{Kn}+2$, 4$\mathrm{D}$ induced only callus. The present study recommends micropropagation for commercial cultivation of this medicinally important species.
\end{abstract}

Key words: Ethnobotany, Asclepias curassavica, Micropropagation, Plantlet regeneration

\section{INTRODUCTION}

Asclepias curassavica L. (Vadoi Tita Phul- Assamese) is an evergreen perennial subshrub of Apocynaceae (subfam. Asclepiadoideae) that grows up to $1 \mathrm{~m}$ and have pale gray stem with milky latex. Leaves are lanceolate or oblong-lanceolate, entire with acuminate or acute tip. The flowers bourn in terminal cymes with 10-20 flowers in each. Corolla purple or red. Seed ovoid, elongated, dark brown. Though it is one naturalized exotic species in India and more particularly in East Himalayan regions.

In recent past the ethnobotanical importance of $A$. cusassavica has been recognized by many researchers. Neto et al. (2002) reported that dried aerial part is used for nasopharyngeal cancer, tumors and warts; Gupta et al. (1971) and ZamoraMartinez and Pola (1992) reported that entire plant is taken orally to treat intestinal parasites and also to treat cold induced headache. The latex from leaf is placed over the affected molar-teeth and leaf-decoction is used to treat gall bladder aches; Coee and Anderson (1996) reported that bark is orally administered in diarrhea, worms and intestinal parasites; Martinez (1984) mentioned that decoction of entire dried plantis used to treat pimples; Coee and Anderson (1996) reported that decoction is taken orally for hemorrhoids of adults and also for diarrhea; Hirschmann et al. (1990) reported its uses to control ticks; Zargari (1992) reported that fresh exudates used on cornsfor human adultsand dried flower and leafapplied on wounds to enhance the healing process, fresh leaf used as an anthelmintic agent; Flores and Ricalde (1996) reported that leaf-latexis used for warts; and the extract of dried leaf is used as an anthelmintic. 
The juice contains a crystalline substance of resinous character, closely allied to lactucone called Asclepione and also wax-like fatty matter, caoutchouc, gum, sugar, salts of acetic acid and other salts. The milky juice can eliminate warts and skin parasites and the decoction of its roots is used for relieving constipation and curing venereal diseases, kidney stones, piles, etc. the plant has capacity to produce hydrocarbon which can use as a crude oil in near future (Reddy et al. 2012).

India has one of the oldest, richest and most diverse cultural traditions associated with the use of medicinal plants. The major concern is that about $95 \%$ of medicinal plants are collected from their wild habitat and over $70 \%$ of plant collections involve destructive harvesting mainly because of the use of the plants parts like bark, roots, wood and whole plants (Tiwari 1999) and that hassled to indiscriminate exploitation from their natural habitat (Tiwari et al.1998). The need of the hour is cultivate such plants and to multiply those in ex situ conditions to meet the increasing demands. The application of in vitro techniques have been routinely practiced for the multiplication of many medicinal plants to meet the demands of pharmaceutical firms and to protect the natural population of rare and endangered plant species (Arora \& Bhojwani 1989; Chttopadhyay et al. 1995; Sudha \& Seeni 1996; Rani \& Grover 1999; Bringmann et al. 1999; Saini \& Jaiswal 2000).

In vitro culture has already gained importance due to quick and large-scale multiplication, ex situ conservation and to produce virus-free plantmaterials (Mathur 2013). Morphogenetic investigations of different explants of Asclepias rotundifolia were carried out by Tideman and Hawker (1983). Looking into the importance of this ethnomedicinal plant species an attempt for the micropropagation through node culture has been done.

\section{MATERIALS AND METHODS}

\section{Plant material:}

Healthy apical shoot buds and young shoot cutting of Asclepias curassavica L. (Apocynaceae), each bearing four to five nodes were collected from naturally growing plants from the nearby area of Defense Research Laboratory, Tezpur $\left(26.6901^{\circ} \mathrm{N} \& 92.7774^{\circ}\right.$ E) area of Assam. After removing the leaves, the shoot apices and nodal segments were washed thoroughly under running tap water. Maximum number of shoot regeneration was achieved from explants taken from 6 to 7 days old seedlings (Chattopadhyay et al. 1995). Explants were surface sterilized by dipping in $70 \%$ ethanol for 1 minute, followed by $0.1 \%$ $\mathrm{HgCl}$, for 2 minutes. Then those were washed thoroughly with water contains $1-2$ drops of Extra and then with sterile distilled water. The stem segments were further cut into $1 \mathrm{~cm}$ pieces having one node and were used as explants. Sections with one node and immature axillary buds were inoculated on sterilized MS medium (Murashige \& Skoog 1962) under aseptic condition containing $1-2$ drops of Extran.

\section{Culture medium and condition}

The culture medium used for the present work was MS-medium (Murashige \& Skoog 1962) supplemented with $100 \mathrm{mg} / 1$ myo-inositol, $3 \%$ sucrose and $8 \%$ agar for the present study. The medium was also supplemented with different concentration of plant growth regulators like BA, IBA, NAA, 2,4-d and $\mathrm{Kn}$, singly or in combination. The $\mathrm{p}^{\mathrm{H}}$ of the medium was adjusted to 5.7. The media were sterilized at $15 \mathrm{lb}$ pressure at $121^{\circ} \mathrm{C}$ for 15 minutes. Aseptic condition was maintained throughout the whole operation. Cultures were maintained at $25 \pm 2^{\circ}$ Cunder fluorescent light of about 3000 lux with 16 hrs of photo period/ day. 
Plantlets with well-developed roots were removed from culture medium and after washing the roots gently under running tap-water were transferred to pots containing autoclaved garden soil. Pots were then irrigated with half strength MS solution for 1 week and subsequently with sterile distilled water. The plants were acclimatized under laboratory condition before transferring to garden net-house and then to natural field conditions.

\section{RESULT AND DISCUSSION}

In the present study, different combinations of plant growth regulators (BA, IBA, NAA, Kn, 2, 4-D) and $100 \mathrm{mg} / \mathrm{L}$ of Casein hydrolysate were tried. Asclepias curassavica did not respond to produce multiple shoots in cluster in all the combinations of applied hormones. The explants swelled considerably within 1-2 weeks of culture and showed profuse callus formation. The regeneration of complete plants of Asclepias was observed with shoot formation followed by rooting. This paper reports that the combination of PGRs in nutrient media is useful forin vitro propagation of this species.

Nodes with axillary buds were cultured on MS medium supplemented with various concentrations of kinetin and IBA. Among all concentrations tried $0.5 \mathrm{mg} / \mathrm{L}$ gave better response resulting with 3 shoots with good amount of roots. The other combinations also resulted in producing roots and shoots (Table1). Kinetin and IBA in lower concentrations were not effective for multiple shoots formation from nodal explants. Kinetin concentration

Table 1. Response of Kinetin and IBA on nodal explants of Asclepias curassavica L. on MS medium.

\begin{tabular}{|c|c|c|c|c|l|l|l|l|}
\hline \multicolumn{2}{|l|}{$\begin{array}{l}\text { MS medium + } \\
\text { PGRs (mg/L) }\end{array}$} & \multicolumn{2}{l|}{$\begin{array}{l}\text { Intensity of } \\
\text { Development }\end{array}$} & \multicolumn{1}{l|}{ Gradual Development in days } \\
\hline Kn & IBA & C & S & R & \multicolumn{2}{l|}{30} & 60 & \multicolumn{1}{l|}{} \\
\hline $\mathbf{0 . 5}$ & 0.5 & - & ++ & - & $\begin{array}{l}\text { Axillary bud opened } \\
\text { and initial callus } \\
\text { started at the base }\end{array}$ & $\begin{array}{l}\text { Callus at } \\
\text { the base }\end{array}$ & $\begin{array}{l}3 \text { shoots, 6- } \\
7 \text { leaves }\end{array}$ & $\begin{array}{l}3 \text { shoots, } 3 \\
\text { roots }\end{array}$ \\
\hline $\mathbf{2 . 0}$ & 0.5 & - & ++ & + & Axillary bud opened & $\begin{array}{l}3 \text { shoots, } \\
\text { basal callus }\end{array}$ & 3 shoots & $\begin{array}{l}3 \text { shoots \& } \\
2 \text { roots }\end{array}$ \\
\hline $\mathbf{2 . 5}$ & 0.5 & + & ++ & + & Axillary bud opened & $\begin{array}{l}\text { 2 shoots, } \\
\text { basal } \\
\text { callus }\end{array}$ & $\begin{array}{l}3 \text { shoots; } \\
\text { leaves } \\
\text { starts } \\
\text { falling }\end{array}$ & $\begin{array}{l}3 \text { shoots } \\
\text { \& 2 roots, } \\
\text { leaves fell } \\
\text { down }\end{array}$ \\
\hline $\mathbf{2 . 5}$ & 0.1 & ++ & ++ & + & $\begin{array}{l}\text { Axillary bud opened. } \\
\text { Callus initiation at } \\
\text { the base }\end{array}$ & $\begin{array}{l}\text { Elongation } \\
\text { of bud, } 10 \\
\text { leaves }\end{array}$ & 2 shoots & $\begin{array}{l}\text { Rooting } \\
\text { (3) started }\end{array}$ \\
\hline
\end{tabular}

C: Callus, S: Shoots, R: Roots

Response types $=+++$ - Excellent, ++ - Good, + - positive

was gradually increased $(0.5,1.0,1.5,2.0,2.5 \mathrm{mg} / \mathrm{L})$ and tried in combination with IBA $(0.1$ and $0.5 \mathrm{mg} / \mathrm{L}$ ) which yielded better results. On increasing kinetin concentration to $0.5 \mathrm{mg} / 1$ and combining it with $0.5 \mathrm{mg} / \mathrm{L}$ IBA induced small callus development with regeneration of 3 shoots and roots on MS medium. In other MS medium samples regeneration of shoot with roots was observed in increasing kinetin concentration $(2.0+0.5,2.5+0.5,2.5+0.1 \mathrm{mg} / \mathrm{L})$ with 0.5 and $0.1 \mathrm{mg} / \mathrm{L}$ IBA. The generation of shoot was also observed on MS medium containing IBA $(0.1 \mathrm{mg} / \mathrm{L})$ plus $\mathrm{Kn}(2.5 \mathrm{mg} / \mathrm{L})$. 
MS medium was also supplemented with kinetin and NAA in various concentrations. The axillary budexplants showed best results in kinetin $0.1 \mathrm{mg} / 1$ and NAA $0.1 \mathrm{mg} / 1 \mathrm{among}$ all the combinations tried. In all concentrations response was quite good. The root development was also very good after 120 days of inoculation (Table 2). In MS medium kinetin ( 0.1 and $2.0 \mathrm{mg} / \mathrm{L})$ with lower concentration of NAA $(0.5 \mathrm{mg} / \mathrm{L})$ explants died within 60 days. When kinetin concentration was increased to $1.0 \mathrm{mg} / \mathrm{L}$ and combined with $0.1 \mathrm{mg} / \mathrm{L}$ NAA callus with good growth was produced (Table 2) but with no organogenesis. Multiple shoots developed from the axillary buds with callus at the base in lower concentrations of kinetin plus NAA $(0.1+0.1 \mathrm{mg} / \mathrm{L})$ in MS medium. Other shoot developing concentrations are $0.5+$ $0.5,1.5+0.5,1.5+1.0 \mathrm{mg} / \mathrm{L}$, kinetin and NAA for MS medium. Moderate concentration of NAA $(0.1 \mathrm{mg} / \mathrm{L})+\mathrm{Kn}(0.1 \mathrm{mg} / \mathrm{L})$ had the maximum shoot generation with root formation.

Table2. Response of Kinetin and NAA on nodal explants of Asclepias curassavica L. on MS medium

\begin{tabular}{|c|c|c|c|c|c|c|c|c|}
\hline \multicolumn{2}{|c|}{$\begin{array}{l}\text { MS medium + } \\
\text { PGRs }(\mathrm{mg} / \mathrm{L})\end{array}$} & \multicolumn{3}{|c|}{$\begin{array}{c}\text { Intensity of } \\
\text { Development }\end{array}$} & \multicolumn{4}{|c|}{ Gradual Development in days } \\
\hline $\mathrm{Kn}$ & NAA & $\mathrm{C}$ & $\mathrm{S}$ & $\mathrm{R}$ & 30 & 60 & 90 & 120 \\
\hline 0.1 & 0.1 & ++ & +++ & ++ & $\begin{array}{l}\text { Axillary bud } \\
\text { opened, } \\
\text { elongated, } \\
7 \text { leaves }\end{array}$ & $\begin{array}{l}2 \text { shoots, } \\
\text { basal } \\
\text { callus }\end{array}$ & 5 shoots & $\begin{array}{l}\text { Rooting (2) } \\
\text { at the base. }\end{array}$ \\
\hline 0.5 & 0.5 & ++ & +++ & ++ & $\begin{array}{l}\text { Axillary bud } \\
\text { opened }\end{array}$ & $\begin{array}{l}\text { Elongatio } \\
n \text { of shoot }\end{array}$ & 2 shoots & $\begin{array}{l}\text { Rooting ( } 2) \\
\text { at the base }\end{array}$ \\
\hline 1.0 & 0.1 & +++ & - & - & $\begin{array}{l}\text { Axillary bud } \\
\text { opened }\end{array}$ & $\begin{array}{l}\text { Only } \\
\text { callus }\end{array}$ & Callus & - \\
\hline 1.5 & 0.5 & - & ++ & + & $\begin{array}{l}\text { Axillary bud } \\
\text { opened, }\end{array}$ & $\begin{array}{l}\text { Elongatio } \\
n \text { of bud }\end{array}$ & 2 shoots & $\begin{array}{l}2 \text { shoots \& } \\
\text { only one } \\
\text { root }\end{array}$ \\
\hline 1.5 & 1.0 & - & ++ & + & $\begin{array}{l}\text { Axillary bud } \\
\text { opened }\end{array}$ & 2 shoots & 3 shoots & $\begin{array}{l}3 \text { shoots \& } \\
2 \text { roots }\end{array}$ \\
\hline
\end{tabular}

C: Callus, S: Shoots, R: Roots

Response types $=+++$ - Excellent, ++ - Good, + - positive

Again, explants were tried on the MS medium supplemented with kinetin and 2,4-D in various concentrations. The growth of the explants was not satisfactory in lower concentrations. But in higher concentrations there was callus formation. Kinetin $(0.1,0.5$, $1.0,1.5,2.0,2.5 \mathrm{mg} / \mathrm{L})$ and $2,4-\mathrm{D}(0.1,0.5,0.1,1.0 \mathrm{mg} / \mathrm{L})$ were used in different combinations. Callus formation was evident in certain combinations without organogenesis. In MS medium with higher concentrations of kinetin $(1.0,1.5$ and $2.0 \mathrm{mg} / \mathrm{L})$, lower concentration of 2,4-D $(0.1$ and $0.5 \mathrm{mg} / \mathrm{L})$ and both kinetin $2.5(\mathrm{mg} / \mathrm{L})$ and 2,4-D $(1.0 \mathrm{mg} / \mathrm{L})$ in higher concentration together explants developed only callus without organogenesis. The callus induction was very good with combination of $\mathrm{Kn}(2.5 \mathrm{mg} / \mathrm{L})$ plus 2 , 4-D $(1.0 \mathrm{mg} / \mathrm{L})$.

The growth of the explants was satisfactory on the medium supplemented with BA and NAA. More number of shoots was observed with excellent growth in the concentrations of BA (1.0 and $1.5 \mathrm{mg} / \mathrm{L})$ and NAA $(0.5$ and $1.0 \mathrm{mg} / \mathrm{L})$ after 90 days. Rooting was also good. A few combinations resulted in producing only small calluses and these are not presented in the table (Table 3 ). 

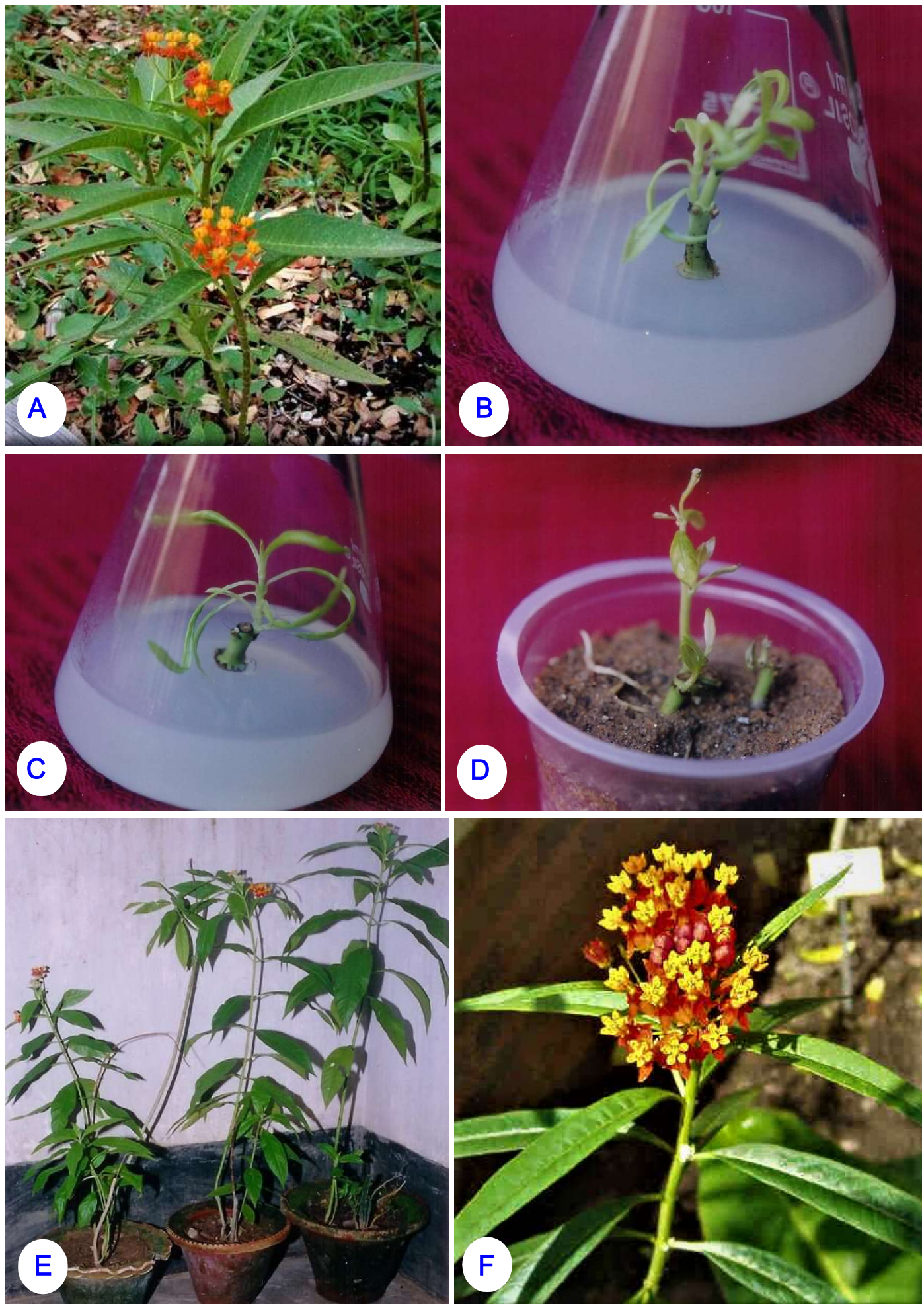

PLATE - I: A. Asclepias curassavica L. in natural habitat; B. Micropropagation under MS media; C. Development of leaf, shoots and roots; D. Transferred to soil for hardenimg; E. Full grown plants in pots; F. Micropropagated matured plant in field with full bloom. 
Table 3. Response of Kinetin and 2,4-D on nodal explants of Asclepias curassavica L. on MS medium.

\begin{tabular}{|c|c|c|c|c|c|c|c|c|}
\hline \multicolumn{2}{|c|}{$\begin{array}{l}\text { MS medium } \\
+ \text { PGRs } \\
(\mathrm{mg} / \mathrm{L})\end{array}$} & \multicolumn{3}{|c|}{$\begin{array}{l}\text { Intensity of } \\
\text { Development }\end{array}$} & \multicolumn{4}{|c|}{ Gradual Development in days } \\
\hline Kn & 2, 4-D & $\mathrm{C}$ & $\mathrm{S}$ & $\mathrm{R}$ & 30 & 60 & 90 & 120 \\
\hline 0.1 & 0.1 & +++ & - & - & $\begin{array}{l}\text { Callusing } \\
\text { started }\end{array}$ & Only callus & $\begin{array}{l}\text { Only } \\
\text { callus }\end{array}$ & $\begin{array}{l}\text { No } \\
\text { organogenesis }\end{array}$ \\
\hline 0.1 & 0.5 & + & + & - & $\begin{array}{l}1 \text { shoot with } 4 \\
\text { leaves, callus } \\
\text { at base }\end{array}$ & $\begin{array}{l}\text { Leaves fell } \\
\text { and callus } \\
\text { died }\end{array}$ & $\begin{array}{l}\text { No } \\
\text { developm } \\
\text { ent }\end{array}$ & $\begin{array}{l}\text { No } \\
\text { development }\end{array}$ \\
\hline 1.0 & 0.5 & +++ & + & - & $\begin{array}{l}1 \text { shoot with } 4 \\
\text { leaves, callus } \\
\text { at the base }\end{array}$ & $\begin{array}{l}\text { Leaves fell, } \\
\text { callus } \\
\text { Remained }\end{array}$ & $\begin{array}{l}\text { Only } \\
\text { callus }\end{array}$ & - \\
\hline 1.5 & 0.5 & ++ & + & - & $\begin{array}{l}1 \text { shoot with } 5 \\
\text { leaves, callus } \\
\text { at base }\end{array}$ & $\begin{array}{l}\text { Leaves fell, } \\
\text { only callus }\end{array}$ & Callus & - \\
\hline 2.5 & 1.0 & +++ & - & - & $\begin{array}{l}\text { Callusing } \\
\text { started }\end{array}$ & Only callus & $\begin{array}{l}\text { Only } \\
\text { enlarged } \\
\text { callus }\end{array}$ & \begin{tabular}{|l|} 
No \\
organogenesis
\end{tabular} \\
\hline
\end{tabular}

C: Callus, S: Shoots, R: Roots

Response types $=+++$ - Excellent, ++ - Good, + - positive

On MS medium in lower concentrations of BA plus NAA $(0.1,0.5 \mathrm{mg} / \mathrm{L})$ and in a higher concentration $2.0+0.5 \mathrm{mg} / \mathrm{L}$ explants died within 60 days. But increasing BA concentration to 1.0 and $1.5 \mathrm{mg} / \mathrm{L}$ with NAA 0.5 and $1.0 \mathrm{mg} / \mathrm{L}$ axillary bud developed higher number of shoots with excellent growth after 90 days. Rooting was good. Single shoot with a few roots developed in the combinations of $2.0+0.1,3.0+0.1,3.0+0.5,4.0+0.5$ and $4.0+2.0$ $\mathrm{mg} / \mathrm{IBA}$ plus NAA in MS medium. Well-developed callus formation was observed in the combinations of $1.0+0.1,1.5+0.5 \mathrm{mg} / 1 \mathrm{BA}$ and NAA on MS medium. MS medium also tried with BA and IBA. Best shooting was observed in the combination BA $(1.5 \mathrm{mg} / \mathrm{L})$ and IBA $(0.5 \mathrm{mg} / \mathrm{L})$. In the same combination when kept more than 90 days, the explants with shoots and roots dried up. On the other hand BA and IAA showed better response in MS medium on increasing BA concentration to $1.0 \mathrm{mg} / 1$ and combining it with $1.0 \mathrm{mg} / \mathrm{L}$, IAA prominent callus developed with shoots and roots. Rajore and Batra (2005) found maximum proliferation of shoot in Jatropha curcas L. with the combination of BAP $(2.0 \mathrm{mg} / 1)$ and IAA $(0.5 \mathrm{mg} /$ $1)$.

Well-developed plantlets from MS medium with prominent roots were directly transplanted to plastic pots containing sterilized soil as the medium. Pots were filled with sterilized sand and well-rotten cow dung. Pots with seedlings were kept inside the laboratory under controlled light $(3000-4000 \mathrm{Lux})$ and temperature $\left(25 \pm 1^{0} \mathrm{C}\right)$ for 30 days and then taken outside to natural conditions. The media were moistened with MS nutrient solution 
Table 4. Response of BA, NAA, IBA and IAA on nodal explants of Asclepias curassavica L. on MS medium

\begin{tabular}{|c|c|c|c|c|c|c|c|c|}
\hline \multicolumn{2}{|c|}{$\begin{array}{l}\text { MS medium } \\
\text { + PGRs } \\
(\mathrm{mg} / \mathrm{L})\end{array}$} & \multicolumn{3}{|c|}{$\begin{array}{c}\text { Intensity of } \\
\text { Development }\end{array}$} & \multicolumn{4}{|c|}{ Gradual Development in days } \\
\hline $\mathbf{B A}$ & NAA & $\mathrm{C}$ & $\mathrm{S}$ & $\mathrm{R}$ & 30 & 60 & 90 & 120 \\
\hline 1.0 & 0.5 & ++ & ++ & ++ & $\begin{array}{l}\text { Axillary bud } \\
\text { Opened }\end{array}$ & $\begin{array}{l}\text { Two shoots } \\
\text { Basal callus }\end{array}$ & $\begin{array}{l}3 \text { shoots, } 5 \\
\text { roots, } \\
\text { callus }\end{array}$ & - \\
\hline 1.5 & 1.0 & + & ++ & ++ & $\begin{array}{l}\text { Axillary bud } \\
\text { developed into } 5 \\
\text { leaved shoot }\end{array}$ & $\begin{array}{l}3 \text { micro } \\
\text { shoots, } \\
\text { callus }\end{array}$ & $\begin{array}{l}3 \text { shoots } \\
\text { with } 4 \\
\text { roots }\end{array}$ & $\begin{array}{l}\text { If not } \\
\text { transferred } \\
\text { died }\end{array}$ \\
\hline 2.0 & 0.1 & + & + & ++ & $\begin{array}{l}\text { Axillary bud } \\
\text { Opened }\end{array}$ & $\begin{array}{l}\text { Single } \\
\text { shoot, callus }\end{array}$ & $\begin{array}{l}\text { Shoot, } \\
\text { callus }\end{array}$ & $\begin{array}{l}\text { Single shoot } \\
\text { with } 3 \text { roots }\end{array}$ \\
\hline 3.0 & 0.1 & - & + & ++ & $\begin{array}{l}\text { Axillary bud } \\
\text { Opened }\end{array}$ & $\begin{array}{l}\text { Shoot } \\
\text { elongated }\end{array}$ & shoot & $\begin{array}{l}\text { Single shoot } \\
\text { with } 3 \text { roots }\end{array}$ \\
\hline 3.0 & 0.5 & + & ++ & + & $\begin{array}{l}\text { One shoot with } \\
4 \text { leaves, callus } \\
\text { at the base }\end{array}$ & $\begin{array}{l}\text { Shoot } \\
\text { elongated } \\
\text { with } 10 \\
\text { leaves }\end{array}$ & 1 shoot & $\begin{array}{l}\text { Single shoot } \\
\text { with } 2 \text { roots }\end{array}$ \\
\hline 4.0 & 0.5 & + & ++ & + & $\begin{array}{l}\text { Axillary bud } \\
\text { Opened }\end{array}$ & $\begin{array}{l}\text { Single } \\
\text { shoot, callus }\end{array}$ & $\begin{array}{l}1 \text { shoot, } \\
\text { Callus }\end{array}$ & $\begin{array}{l}\text { Single shoot } \\
\text { with } 3 \text { roots }\end{array}$ \\
\hline 4.0 & 2.0 & - & + & + & $\begin{array}{l}\text { One shoot, no } \\
\text { callus }\end{array}$ & $\begin{array}{l}\text { Shoot } \\
\text { elongated }\end{array}$ & $\begin{array}{l}\text { One shoot } \\
\text { with roots, } \\
\text { no callus }\end{array}$ & $\begin{array}{l}\text { One plantlet } \\
\text { with } 3 \text { roots }\end{array}$ \\
\hline BA & IBA & & & & & & & \\
\hline 1.5 & 0.5 & ++ & ++ & ++ & 2 shoots, callus & $\begin{array}{l}4 \text { shoots } \\
\text { with } 6 \text { roots }\end{array}$ & $\begin{array}{l}\text { If not } \\
\text { transferred } \\
\text { died }\end{array}$ & - \\
\hline $\mathbf{B A}$ & IAA & & & & & & & \\
\hline 1.0 & 1.0 & + & ++ & ++ & $\begin{array}{l}\text { Enlarged } \\
\text { axillary bud } \\
\text { opened }\end{array}$ & $\begin{array}{l}1 \text { shoot. } 5 \\
\text { leaves }\end{array}$ & $\begin{array}{l}2 \text { micro } \\
\text { shoot, } 5 \\
\text { roots. } \\
\text { callus }\end{array}$ & $\begin{array}{l}\text { If not } \\
\text { transferred } \\
\text { died }\end{array}$ \\
\hline 2.0 & 0.1 & - & + & + & $\begin{array}{l}\text { Very little } \\
\text { development }\end{array}$ & $\begin{array}{l}\text { Very little } \\
\text { developmen } \\
t\end{array}$ & 1 shoot & $\begin{array}{l}\text { Single shoot } \\
\text { with } 2 \text { roots }\end{array}$ \\
\hline 2.0 & 0.5 & - & + & + & $\begin{array}{l}\text { Axillary bud } \\
\text { Opened }\end{array}$ & $\begin{array}{l}\text { Shoot } \\
\text { elongated }\end{array}$ & 1 shoot & $\begin{array}{l}\text { Single shoot } \\
\text { with } 3 \text { roots }\end{array}$ \\
\hline 3.0 & 0.5 & + & ++ & + & $\begin{array}{l}\text { One shoot with } \\
4 \text { leaves callus } \\
\text { At the base }\end{array}$ & $\begin{array}{l}\text { Shoot } \\
\text { elongates, } \\
10 \text { leaf } \\
\text { structure }\end{array}$ & Shoot & $\begin{array}{l}1 \text { shoot with } \\
3 \text { roots }\end{array}$ \\
\hline
\end{tabular}

C: Callus, S: Shoots, R: Roots

Response types $=+++$ - Excellent, ++ - Good, + - positive

(without sugar and agar) on which the growth was best and water was sprayed once a week. After 120 days from the time of culture the plantlets were taken out of flasks and transferred to soil. Plantlets derived from aerial buds were greater in number and showed 
good growth.30 days of transfer percentage of survival of plantlets were determined so that regenerating media with maximum viable plantlets can be identified.

\section{CONCLUSION}

The present investigation reports a detailed protocol for successful rapid clonal propagation with high rate of shoots multiplication with good rooting and excellent establishment in the soil with excellent growth performance. The production of Asclepias currasavica has increased up to minimum two times after macro proliferation. It is suggested that using this method the protocol will meet the growing demand for true-to type, disease free and high quality planting materials. Therefore, in vitro propagation is the best method to obtain clonally uniform planting materials for this economically and medicinally important species of plant.

\section{Acknowledgements}

Authors are thankful to the Head, Department of Botany, Gauhati University for tissue culture laboratory facilities and also to North East Council (NEC) for financial support to carry out the work.

\section{LITERATURE CITED}

Arora, R. \& Bhojwani, S.S. 1989. In vitropropagation and low temperature storage of Saussurea lappa C.B Clarke - an endangered medicinal plant. Plant Cell Rep. 8: 44 - 47.

Bringmann, G.; Rischer, H.; Schlaver, J. \& Asssi, A. 1999. In vitro propagation of Ancistrocladus abbreviates Airy Shaw (Ancistrocladaceae). Pl. Cell Tiss. Org. Cult. 57: $71-73$.

Chattopadhyay, S.; Dutta, S.K. \& Mahato, S.B. 1995.Rapid micropropagation for Mucuna pruriens f. pruriens L. Pl. Cell Rep. 15: $271-273$.

Coee, F.G. \& Anderson, G.J. 1996. Ethnobotany of the Garifuna of Eastern Nicaragua. Econ. Bot.. 50(1): $71-107$.

Flores, J.S. \& Ricalde, R.V. 1996. The secretions and exudates of plants used in Mayan traditional medicine. J. Herb. Spice. Med. Pl. 4(1): 53 - 59.

Gupta, M.L.; Gupta, T.K. \& Bhargava, K.P.A. 1971. Study of antifertility effects of some indigenous drugs. J. Res. Indian Med. 6: 112 - 116.

Hirschmann, G.S.; Rojas, D.E. \& Arias, A. 1990 A survey of medicinal plants of minas gerais, brazil. J. Ethnopharm. 29(2):159 - 172.

Martinez, M.A. 1984. Medicinal plants used in a totonac community of the sierra norte de puebla: tuzamapan de Galeana, Puebla, México. J. Ethnopharm. 11 (2): 203 - 221.

Mathur, S. 2013 Conservation of Biodiversity through tissue culture. Research and Reviews: J. Microb. Biotech. 2(3): $01-06$.

Murashige, T. \& Skoog, F. 1962. A revised medium for rapid growth and bioassay with tobacco tissue culture. Pl. Physiol. 15: $473-497$.

Neto, C.C.; Owens, C.W.; Langfield, R.D.; Comeau, A.B.; Onge, J.S.; Vaisberg, A.J. \& Hammond, G.B.2002. Antibacterial activity of some Peruvian medicinal plants from the callejon de huaylas. J. Ethnopharm. 79(1): 133 - 138.

Rajore, S. \& Batra, A. 2005. Efficient Plant Regeneration via shoot tip explants in Jatropha curcas L. J. Pl. Biochem. Biotech. 14: 73 - 75. 
Rani, G. \& Grover, I.S. 1999. In vitro callus induction and regeneration studies in Withania somnifera (L.) Dunal. Pl. Cell Tissue Org. Cult. 1: 23 - 27.

Reddy, S.H.; Chakravarthi, M. \& Chandrasekhara, K.N. 2012. In vitro multiple shoot induction through axillary bud of $A$. curassavica L. - a valuable medicinal plant. Intn. J. Sci. Res. Publ. 8(2): $01-07$.

Saini, R. \& Jaiswl, P.K. 2000. In vitro multiplication of Peganumharmala an important medicinal plant.Ind. J. Expt. Biol. 38: 499 - 503.

Sudha, T.G. \& Suni, S. 1996. In vitro propagation of Rauvolfia micrantha, a rare medicinal plant. Pl. Cell. Tiss. Org. Cult. 44: $243-248$.

Tideman, J. \& Hawkar, J.S. 1983 Tissue culture of latex bearing plants. Inc Proc Austr Plant Tissue Culture Conf, 2 meet, 24.

Tiwari, D.N. 1999. Medicinal plant for health care. Yojona, Min. Inf. Broadc., India 44: 8 $-17$.

Tiwari, K.P.; Shrivastava, J.L. \& Sharma, M.C. 1998. Medicinal Plants of Madhya Pradesh - distribution, cultivation and Trade. Bull. No. 31, State Forest Research Institute, Jabalpur 47.

Zamora-Martinez, M.C. \& Pola, C.N.P. 1992. Medicinal plants used in some rural populations of Oaxaca, Puebla and Veracruz, Mexico. J. Ethnopharm. 35(3): 229 - 257.

Zargari, A. 1992.Medicinal Plants. Vol. 3, $5^{\text {th }}$ edn., Tehran University Publications, Tehran, Iran. P-889. 